\title{
FGFR3 Gene Fusion Positive
}

National Cancer Institute

\section{Source}

National Cancer Institute. FGFR3 Gene Fusion Positive. NCI Thesaurus. Code C148097.

An indication that a FGFR3 fusion gene has been detected in a sample. 